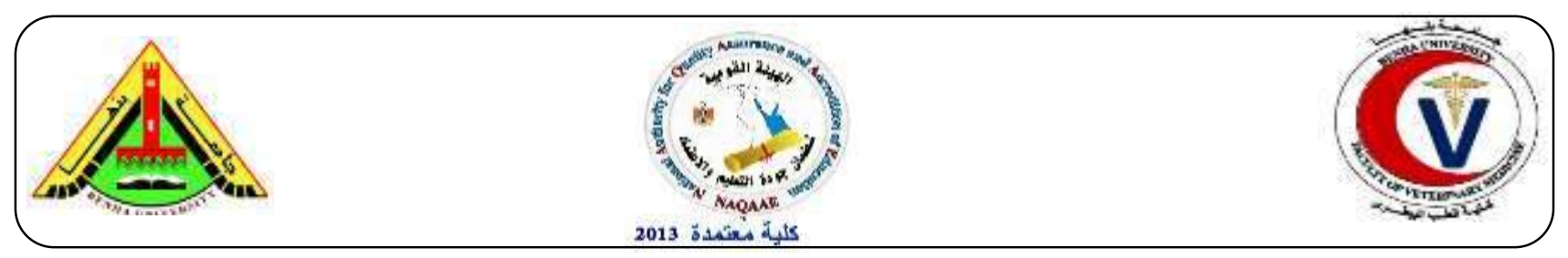

\title{
Prevalence of salmonella in some chicken meat products
}

\author{
Shaltout, Fahim ${ }^{1}$; Nada, Shaimaa $\mathrm{M}^{2}$; wahba, samah fawzy ${ }^{3}$ \\ ${ }^{I}$ Department of Food Hygiene and Control, Faculty of Veterinary Medicine, Benha University \\ ${ }^{2}$ Animal Health Research Institute, Dokki, Giza \\ ${ }^{3}$ Department of Meat Hygiene, Faculty of Veterinary Medicine, Menofyia University
}

\begin{abstract}
A B S T R A C T
A total of 90 random samples of various chicken meat products were collected from different markets in Menofia governorate, Egypt, represented by 30 equal samples of fresh chicken cuts-up (skinless and boneless breast and thigh) (15 of each) 30 equal samples of frozen breaded half cooked chicken products (chicken nuggets and chicken panne) (15 of each) and 30 equal samples of cooked chicken products(Shawerma and Fahita sandwiches) (15 of each).The mean values of APC (cfu/g) in the examined samples of chicken breast, thigh, panne, nuggets, shawerma and chicken fahita, were $5.5 \times$ $10^{6} \pm 1.51 \times 10^{6}, 6.8 \times 10^{6} \pm 1.3 \times 10^{5}, 3.1 \times 10^{5} \pm 1.7 \times 10^{4}, 4.5 \times 10^{5} \pm 1.2 \times 10^{4}, 2.2 \times 10^{4} \pm 1.5 \times 10^{4} \&$ $4.9 \times 10^{4} \pm 1.5 \times 10^{4}$, for APC and $3.5 \times 10^{4} \pm 1.7 \times 10^{4}, 7.8 \times 10^{4} \pm 1.4 \times 10^{4}, 4.8 \times 10^{3} \pm 1.5 \times 10^{2}, 6.5 \times$ $10^{3} \pm 1.7 \times 10^{1}, 3.8 \times 10^{2} \pm 1.5 \times 10^{2}$ and $4.1 \times 10^{2} \pm 1.0 \times 10^{2}$, for Enterobacteriaceae count, respectively. Salmonella Typhimurium was detected in $13.3 \%, 20 \%$ and $6.7 \%$ of breast, thigh and panne samples respectively while Salmonella Anatum was detected in $7 \%$ of nuggets samples. On the other hand, Salmonella enteritidis was detected in $13.3 \%$ of breast samples and in $6.7 \%$ of both thigh and panne samples .Salmonella Heidelberg, Salmonella Muenster and Salmonella Kentucky were isolated from $6.7 \%$ of some of examined samples. As conclusion, there is a need to educate consumers, food handlers and all others who have access to food about the importance of hygiene and it is necessary to cooking food property.
\end{abstract}

Keywords: chicken meat products, APC, Enterobacteriacea, Salmonella.

(http://www.bvmj.bu.edu.eg) $\quad$ (BVMJ-36(2):33-39, 2019)

\section{INTRODUCTION}

Chicken meat and chicken meat products are very popular foods throughout the world since they are delicious, nutritious, characterized by good flavor and easily digested (Smith, 2001). In Egypt, chicken meat products are winning popularity because they represent quick easily prepared meat meals and solve the problem of the shortage in fresh meat of high price that is not within the reach of large numbers of families with limited income.

The intact tissues of healthy slaughtered birds and animals are mostly sterile but the meat may be contaminated during processing from the hands, workers, clothes, knives, the hide, the gut or from the environment resulting in an underling or even unfit quality for human consumption. Contaminated chicken, and 
chicken products may compose a public health hazard (Ahmed and Ismail, 2010).

The most important bacterial pathogen in chicken meat that causes infection of foodborne infections is Salmonellae (Ahmed, 2014).

Salmonella are found worldwide and universally recognized as zoonotic agent Many foods particularly of animal origin and those subjected to sewage pollution had been identified and must be taken into considerations as a vehicle for transmitting this pathogen to human being. The primary habitat of Salmonella is intestinal tract of animals and humans. Additionally, Salmonella causes illness by means of infection, as it multiplies in the small intestinal, colonizies and subsequently invades the intestinal tissues, producing an enterotoxin and causing inflammatory reaction and diarrhea (ICMSF, 2006).

Persons infected with S. Enteritidis usually has fever, abdominal cramps and diarrhea beginning 12 to 72 hours after consuming contaminated food. The illness usually lasts 4 to 7 days and most persons recover without antibiotic treatment. However, in the elderly, infants and persons with impaired immune systems, diarrhea can be severe and the persons may be ill enough to require hospitalization. In such patients, infection may spread to other body organs and can cause death if prompt antibiotic treatment is not administer (WHO 2005).

The purpose of this study was planned to evaluate the hygienic status of chicken cuts-up (breast and thigh), half cooked chicken products (chicken nuggets and chicken panne) and full cooked chicken products (chicken fahita and shawrma) according to the following topics:

1-Determination of aerobic plate count (APC) 2-Determination of Enterobacteriaceae count.

3-Isolation and identification of Salmonella species.

\section{Materials and methods}

\subsection{Collection of samples:}

Ninety random samples of chicken cuts-up and chicken meat products, classified into of fresh skinless and boneless breast and thigh, frozen breaded half cooked chicken nuggets and chicken panne, cooked chicken Shawerma and Fahita sandwiches (15 of each) were collected from different markets in Menofia governorate, Egypt. The collected samples were transferred in an ice box to the laboratory without undue delay.

2.2. Preparation of the samples (APHA, 2002): Ten grams of each sample was aseptically weighed into $90 \mathrm{ml}$ of $0.1 \%$ peptone water in a sterile plastic bag, and then blended in a Stomacher 400 Lab Blender (Seward Medical, London, UK) for 30 seconds. Accordingly, ten-fold serial dilutions were prepared for bacteriological examination.

\subsection{Bacteriological examination:}

Aerobic plate count and Enterobacteriacea Count were carried out according to APHA, (2002).

Isolation and identification of Salmonellae were carried out according to ISO, (2002). Serological identification of Salmonellae was applied according to Kauffman, (1974).

\section{RESULTS}

It is evident from the result recorded in table (1) ) that the mean values of APC (cfu/g) were $5.5 \times 10^{6} \pm 1.51 \times 10^{6}, 6.8 \times 10^{6} \pm 1.3 \times 10^{5}$, $3.1 \times 10^{5} \pm 1.7 \times 10^{4}, 4.5 \times 10^{5} \pm 1.2 \times 10^{4}$, $2.2 \times 10^{4} \pm 1.5 \times 10^{4}$ and $4.9 \times 10^{4} \pm 1.5 \times 10^{4}$ for the examined samples of chicken breast, thigh, panne, nuggets, shawerma and chicken fahita, respectively. In other words, there were significant differences $(\mathrm{P}<0.01)$ between the examined samples.

According to the safe permissible limit stipulated by ES (2005) No. (1090-2005) for APC in complete poultry carcass, poultry parts and raw poultry products (not exceed $10^{5}$ 
$\mathrm{cfu} / \mathrm{g})$ and No. (3493-2005) for heat treated poultry meat products (not exceed $10^{4} \mathrm{cfu} / \mathrm{g}$ ), it was indicated that $100 \%, 100 \%, 66.6 \%$, $73.3 \%, 26.6 \%, 26.6 \%$ of the examined samples of chicken breast, thigh, panne, nuggets, shawerma, chicken fahita respectively were not in accordance with this limit .

The obtained results in Table (2) revealed that the mean values of total Enterobacteriacae count $(\mathrm{cfu} / \mathrm{g})$ were $3.5 \times 104 \pm 1.7 \times 10^{4}, 7.8 \times$ $10^{4} \pm 1.4 \times 10^{4}, 4.8 \times 10^{3} \pm 1.5 \times 10^{2}, 6.5 \times 10^{3}$ $\pm 1.7 \times 10^{1}, 3.8 \times 10^{2} \pm 1.5 \times 10^{2}$ and $4.1 \times 10^{2} \pm$ $1.0 \times 10^{2}$ for the examined samples of chicken breast, thigh, panne, nuggets, shawerma, chicken fahita respectively. Moreover, significant differences were recorded between the examined samples $(\mathrm{P}<0.05)$.
The recorded results in Table (3) reveald that Salmonella Typhimurium was detected in $13.3 \%, 20 \%$ and $6.7 \%$ of breast, thigh and pane samples respectively while Salmonella Anatum was detected in $7 \%$ of nuggets samples. On the other hand, Salmonella Enteritidis was detected in $13.3 \%$ of breast samples and in $6.7 \%$ of both thigh and panne samples .Salmonella Heidelberg, Salmonella Muenster and Salmonella Kentucky were isolated from $6.7 \%$ of some of examined samples.

Among the examined chicken samples higher incidence of Salmonella is present in thigh samples $(46.6 \%)$ while lower incidence were present in fahita and shawerma.

Table1: Statistical analytical results of Aerobic Plate Count (APC) (cfu /g) in the examined samples of poultry products $(n=15)$.

\begin{tabular}{|c|c|c|c|c|c|c|c|}
\hline \multirow{2}{*}{$\begin{array}{l}\text { Items } \\
\text { Samples }\end{array}$} & \multirow{2}{*}{ Min } & \multirow{2}{*}{ Max } & \multirow{2}{*}{ Mean \pm SE } & \multicolumn{2}{|c|}{$\begin{array}{l}\text { Accepted } \\
\text { samples }\end{array}$} & \multicolumn{2}{|c|}{$\begin{array}{l}\text { Unaccepted } \\
\text { samples }\end{array}$} \\
\hline & & & & No. & $\%$ & No. & $\%$ \\
\hline \multicolumn{8}{|l|}{ 1- Breast } \\
\hline & $2.2 \times 10^{5}$ & $4.9 \times 10^{7}$ & $\begin{array}{l}5.5 \times 10^{6} \pm 1.51 \times \\
10^{6}\end{array}$ & 0 & 0 & 15 & 100 \\
\hline 2- Thigh & $4.8 \times 10^{5}$ & $7.1 \times 10^{7}$ & $\begin{array}{l}6.8 \times 10^{6} \pm 1.3 \times \\
10^{5}\end{array}$ & o & 0 & 15 & 100 \\
\hline 3-Panne & $2.5 \times 10^{3}$ & $5.3 \times 10^{5}$ & $\begin{array}{l}3.1 \times 10^{5} \pm 1.7 \times \\
10^{4}\end{array}$ & 5 & 33.3 & 10 & 66.6 \\
\hline 4- Nuggets & $3.8 \times 10^{3}$ & $7.8 \times 10^{5}$ & $\begin{array}{l}4.5 \times 10^{5} \pm 1.2 \times \\
10^{4}\end{array}$ & 4 & 26.6 & 11 & 73.3 \\
\hline 5-Shawerma & $2.1 \times 10^{3}$ & $3.2 \times 10^{5}$ & $2.2 \times 10^{4} \pm 1.5 \times 10^{4}$ & 11 & 73.3 & 4 & 26.6 \\
\hline 6 - Fahita & $2.3 \times 10^{3}$ & $5.4 \times 10^{5}$ & $4.9 \times 10^{4} \pm 1.5 \times 10^{4}$ & 11 & 73.3 & 4 & 26.6 \\
\hline
\end{tabular}

$\mathrm{S} . \mathrm{E}=$ Standard error of mean. The $\mathrm{P}$ value is $0.0014,(\mathrm{P}<0.01)$ considered significant Variation. Permissible Limit not exceed $10^{5} \mathrm{cfu} / \mathrm{g}$ according to ES (2005) for raw poultry products and $10^{4}$ $\mathrm{cfu} / \mathrm{g}$ for heat treated poultry meat products. 
Table 2: Statistical analytical results of Enterobacteriaceae count (cfu/g) in the examined samples of chicken meat products $(n=15)$.

\begin{tabular}{cccc}
\hline Samples & Min & Max & Mean \pm SE \\
\hline 1- Breast & $3.9 \times 10^{2}$ & $5.2 \times 10^{5}$ & $3.5 \times 10^{4} \pm 1.7 \times 10^{4}$ \\
2- Thigh & $5.1 \times 10^{2}$ & $6.2 \times 10^{5}$ & $7.8 \times 10^{4} \pm 1.4 \times 10^{4}$ \\
3- Panne & $4.2 \times 10^{2}$ & $5.9 \times 10^{4}$ & $4.8 \times 10^{3} \pm 1.5 \times 10^{2}$ \\
4- Nuggets & $5.6 \times 10^{2}$ & $8.0 \times 10^{4}$ & $6.5 \times 10^{3} \pm 1.7 \times 10^{1}$ \\
5-Shawerma & $2.1 \times 10^{2}$ & $4.1 \times 10^{3}$ & $3.8 \times 10^{2} \pm 1.5 \times 10^{2}$ \\
6 - Fahita & $2.2 \times 10^{2}$ & $6.5 \times 10^{3}$ & $4.1 \times 10^{2} \pm 1.0 \times 10^{2}$ \\
\hline
\end{tabular}

The $\mathrm{P}$ value is $0.0058,(\mathrm{P}<0.05)$ considered significant.

Table 3: Incidence of identified Salmonella serotypes isolated from the examined samples of chicken meat products $(n=15)$.

\begin{tabular}{|c|c|c|c|c|c|c|c|c|c|c|c|c|}
\hline \multirow{3}{*}{$\begin{array}{l}\text { Products } \\
\text { Serotype }\end{array}$} & \multicolumn{4}{|c|}{ Raw Products } & \multicolumn{4}{|c|}{ Half cooked } & \multicolumn{4}{|c|}{ Cooked Products } \\
\hline & \multicolumn{2}{|c|}{ Breast } & \multicolumn{2}{|c|}{ Thigh } & \multicolumn{2}{|c|}{ Nuggets } & \multicolumn{2}{|c|}{ Panne } & \multicolumn{2}{|c|}{ Fahita } & \multicolumn{2}{|c|}{ Shawerma } \\
\hline & $\mathrm{N}$ & $\%$ & $\mathrm{No}$ & $\%$ & No & $\%$ & No & $\%$ & No & $\%$ & No & $\%$ \\
\hline S.Typhimurium & 2 & 13.3 & 3 & 20 & 1 & 6.7 & - & - & - & - & - & - \\
\hline S. Enteritidis & 2 & 13.3 & 1 & 6.7 & - & - & 1 & 6.7 & - & - & - & - \\
\hline S. Heidelberg & 1 & 6.7 & 1 & 6.7 & - & - & - & - & - & - & - & - \\
\hline S. Muenster & - & - & 1 & 6.7 & - & - & - & - & - & - & 1 & 6.7 \\
\hline S. Kentucky & - & - & 1 & 6.7 & - & - & 1 & 6.7 & 1 & 6.7 & - & - \\
\hline S. Anatum & - & - & - & - & 1 & 7 & - & - & - & - & - & - \\
\hline Total & 5 & 33.3 & 7 & 46.6 & 2 & 13.3 & 2 & 13.3 & 1 & 6.7 & 1 & 6.7 \\
\hline
\end{tabular}

\section{DISCUSSION}

Chicken meat products are subjected to the risk of contamination with various pathogens from different sources, primary during preprocessing and processing steps and secondary after processing through packaging, marketing and storage. Such contamination may render these food articles unfit for human consumption or even harmful to consumers.
The total aerobic plate count gives an idea about the hygienic measures applied through processing. So, it is the most reliable method for detection of sanitary levels of proper processing, storage and marketing of food products (Jay, 1997).

It is evident from the result recorded in table (1) that the mean values of APC $(\mathrm{cfu} / \mathrm{g}$ ) were $5.5 \times 10^{6} \pm 1.51 \times 10^{6}, 6.8 \times 10^{6} \pm 1.3 \times 10^{5}$, 
$3.1 \times 10^{5} \pm 1.7 \times 10^{4}, 4.5 \times 10^{5} \pm 1.2 \times 10^{4}$, $2.2 \times 10^{4} \pm 1.5 \times 10^{4}$ and $4.9 \times 10^{4} \pm 1.5 \times 10^{4}$ for the examined samples of chicken breast, thigh, panne, nuggets, shawerma and chicken fahita, respectively. In other words, there were significant differences $(\mathrm{P}<0.01)$ between the examined samples.

According to the safe permissible limit stipulated by ES (2005) No. (1090-2005) for APC in complete poultry carcass, poultry parts and raw poultry products (not exceed $10^{5}$ $\mathrm{cfu} / \mathrm{g}$ ) and No. (3493-2005) for heat treated poultry meat products (not exceed $10^{4} \mathrm{cfu} / \mathrm{g}$ ), it was indicated that $100 \%, 100 \%, 66.6 \%, 73.3 \%$, $26.6 \%, 26.6 \%$ of the examined samples of chicken breast, thigh, panne, nuggets, shawerma, chicken fahita respectively were not in accordance with this limit (table 1).

Our results near to that recorded by ( Mahmoud and Hamouda-Seham, 2006) who tested 80 random samples of poultry thigh and breast (40 of each) collected from El- Gharbia governorate and revealed that the mean values of APC (cfu/g) were $1.4 \times 10^{6} \pm 4 \times 10^{5}$ and 6 $\times 10^{5} \pm 2 \times 10^{4}$, respectively. Higher results were reported by Oumokhtar (2000) who recorded that the mean value of APC in chicken meat was $2,9 \times 10^{4} \mathrm{cfu} / \mathrm{g}$ and higher than that recorded by (Shaltout et al, 2015) who recorded that the mean value of APC in raw chicken meat was $3.6 \times 10^{4} \pm 2.1 \times 10^{3}$. The prevalence of Salmonella spp. in chicken meat was $3.12 \%$.

Enterobacteriaceae group has an epidemiological importance (Mercuri et al., 1978).

Table (2) indicated that the mean values of total Enterobacteriacae count (cfu/g) were $3.5 \times$ $10^{4} \pm 1.7 \times 10^{4}, 7.8 \times 10^{4} \pm 1.4 \times 10^{4}, 4.8 \times 10^{3} \pm$ $1.5 \times 10^{2}, 6.5 \times 10^{3} \pm 1.7 \times 10^{1}, 3.8 \times 10^{2} \pm 1.5 \times 10^{2}$ and $4.1 \times 10^{2} \pm 1.0 \times 10^{2}$ for the examined samples of chicken breast, thigh, panne, nuggets, shawerma, chicken fahita respectively. Moreover, significant differences were recorded between the examined samples $(\mathrm{P}<0.05)$.

These results for Enterobactereaceae count is nearly similar results for chicken products were obtained by Shaltout (2002), But this results are higher than that recorded by Saikia and El-Deeb et al., (2011) who was recorded higher results for heat treated chicken meat products and also higher results obtained by (Shaltout et al, 2018) who recorded that the mean value of total enterobactereacea count in chicken Panne and chicken Nuggets were $5.47 \times 104 \pm 1.80 \times 104 \mathrm{cfu} / \mathrm{g}$ and6.58×104 \pm $1.98 \times 104 \mathrm{cfu} / \mathrm{g}$ respectively. While lower Enterobactereacaea count in chicken meat were obtained by Nawar (2007).

Incidence of identified salmonella serotypes isolated from the examined samples of chicken meat products:

Salmonella Typhimurium was detected in $13.3 \%, 20 \%$ and $6.7 \%$ of breast, thigh and pane samples respectively while Salmonella Anatum was detected in $7 \%$ of nuggets samples. On the other hand, Salmonella Enteritidis was detected in $13.3 \%$ of breast samples and in $6.7 \%$ of both thigh and panne samples .Salmonella Heidelberg, Salmonella Muenster and Salmonella Kentucky were isolated from $6.7 \%$ of some of examined samples.

Among the examined chicken samples higher incidence of Salmonella is present in thigh samples $(46.6 \%)$ while lower incidence were present in fahita and shawerma.

The presence of Salmonella in chicken meat may be attributed to contamination during slaughtering and / or processing from workers' hands (Carraminana et al., 1997). Organic matters scattered on the bird surface may harbor Salmonellae and act as a source of contamination to scalding tanks therefore, 
facilitate cross contamination between chicken. Rubber fingers of plucking machine may have several cracks carrying organic matter and act as source of crosscontamination between chickens Moreover, during evisceration step cross-contamination may occur through escape of gut content (Berrang et al, 2011).

\section{CONCLUSION}

The obtained results in the present study concluded that the examined chicken cuts-up (breast and thigh) samples showed higher significant APC and Enterobacteriacea count than the examined chicken nuggets, chicken panne, Shawerma and Fahita sandwiches samples. While Salmonella species was isolated from $33.3 \%, 46.6 \%, 13.3 \%, 13.3 \%$, $6.7 \%, 6.7 \%$ of the examined breast, thigh, nuggets, chicken panne, Shawerma and Fahita samples, respectively. The result demonstrates the fact that the unhygienic and poor sanitary conditions under which the meat are handled not acceptable from sanitary point of view. It has further evidence that the undesirable level of contamination which might have acquired from the environment and to obtain wholesome, safe and sound meat, the Hazard Analysis and Critical Control Point system (HACCP) must be adopted.

\section{REFERENCES}

Ahmed, M. H. (2014): Incidence of Salmonella In heat treated poultry product. M.V.Sci.Thesis (food hygiene and control) Fac. Vet. Med. Cairo Univ.

Ahmed, A. M. and Ismail, T. H. (2010): "Improvement of the quality and shelflife of minced beef mixed with soy protien by Sage (Saliva officinalis)". African J. Food Science, 4:330-334.

APHA, American Public Health Association, (2002): Compendium of methods for microbiological examination of Food $3^{\text {rd }}$ Ed. Brothers, Ann, Arb.
Berrang, M.E.; Windham, W.R. and Meinersmann, R.J. (2011): Campylobacter, Salmonella and Escherichia coli on broiler carcasses subjected to a high $\mathrm{pH}$ scald and low $\mathrm{pH}$ postpick.Poult. Sci., 90:896.

Carraminana, J.J.; Yanguela, J.; Blanco, D.; Rota, C.; Agustin, A.I.: Arino, A. and Herrera, A. (1997): Salmonella incidence and distribution of serotypes throughout processing in a Spanish poultry slaughterhouses. J. Food Prot., 60(11):1312-1317.

El-Deeb, M.F.; EL-Glel, H.A. and Samaha, I.A. (2011): Quality assurance of some poultry meat products ISSN 1102047Alex. J. Vet. Science. 33 (1): 153163.

ES, Egyptian Standard (2005): For complete poultry carcass, poultry parts and raw poultry products (No. 1090-2005) and for heat treated poultry meat products (No. 3493-2005).

ICMSF, International Commission and Microbiological Specification for Foods, (2006): Microorganisms in foods, III Microorganisms specifications of food pathogens .Vol.2, champman and Hall, London, New York.

ISO (2004): International Organization for Standardization, No. 11291-1. Microbiology of food and animal feeding stuffs - Horizontal methods for detection and enumeration of Enterobacteriaceae, part2: colony count, method.

ISO (2002): International Organization for Standardization. No. 6579. Microbiology of food and animal feeding stuffs - Horizontal methods for detection of Salmonella species.

Jay, J.M. (1997): Modern food microbiology, 4th Ed., Chapman and Hall, International Thomson publishing, NewYork.

Kauffmann, F. (1974): Kauffmann white scheme, WHO. BD/72, L., Rev. I. Acta. Path. Microbiol. Scan. 61, 385.

Mahmoud, Y. EL-A. and Hamouda-Seham N. (2006): Quality Evaluation of Poultry Meat Carcass in El- Gharbia 
Governorate Markets.Assiut Vet. Med. J., 52 (110): 31-43.

Mercuri, A.J.; Cox, N.A.; Carson, M.O. and Tanner, D.A. (1978): Relation of Enterobacteriaccae count to Salmonella contamination of Marker broiler. J. Food Protect, 42:427.

Nawar, A.Z. (2007): Correlation between Salmonella and sanitation level in poultry processing plants .M. V. Sc. Thesis (Meat Hygiene) .Fac. Vet. Med. Benha Univ.

Oumokhtar, B. (2000): Qualite' bacte'riologique de viandes, d'abats, de preparations carne'es et d'hurtres commercialise'es a" Rabat. The'se de Doctorat National, Universite' Chouaib Doukkali, Faculte'des Sciences, El Jadida, Morocco.

Saikia, P. and Joshi, S.R. (2010): Retail market poultry meats of NorthEast India.A microbiological survey for pathogenic contaminant. Res. J. Microbiol, 5(1): 36-43.
Shaltout, F.A. (2002): Microbiological aspects of semi-cooked chicken meat products. Benha. V. M. J. (2):17- 19.

Shaltout, F. A.; Zakaria, I. M.; Eltanani- Jehan and Elmelegy- Asmaa,s. (2015): Microbiological status of meat and chicken received to University student hostel.Benha. V. M. J. 29, (2):187-192.

Shaltout, F. A.; Lotfy- Lamiaa.M; El ZahabyDina. I. and El-Shorah- Hala.F. (2018): Bacteriological status of chicken meat products marketed at Menofia governorate. Benha. V. M. J.34, (1):2840.

Smith, D.M. (2001): Functional properties of muscle proteins in processes poultry products. In poultry meat processing. Edd. Sams, A. R., CRC, Press.

World Health Organization WHO (2005): Fact sheet No. 139(Revised April, 2005. http:/www.who.int/mediacentre/factsh eets/ fsl39/en/prnt. Html. 